\title{
The water balance analysis of Kordan Basin (north west of Iran)
}

\author{
H. Moghimi \\ Department of Geology Payam-enoor University, Tehran, Iran
}

\begin{abstract}
As Iran has a semi-arid to arid climate, ground water resource application is of significant importance. The Kordan Basin is also one of the areas that due to excessive application has faced a sharp fall of $2-4 \mathrm{~m}$ in the ground water level in the last 30 years. Thus, in order to determine the parameters affecting the water level fall and to study the Plain aquifer situation, it is necessary to prepare a water balance. Hashtgerd Plain is located in $36^{\circ}-05^{\prime}$ to $36^{\circ}-45^{\prime}$ latitude and $50^{\circ}$ $30^{\prime}$ to $50^{\circ}-55^{\prime}$ longitude. The budget area is $468.45 \mathrm{~km}^{2}$ and located in the north west of Tehran. The balance (budget) elements were examined one by one by applying different methods and the present equations for the ground water, then having applied the general budget equation, the reservoir volume changes for the water year 1996-97 were studied and calculated. In the calculations, two items were considered: first, it was confirmed that there has been a fall in ground water level and a decrease in aquifer reservoir volume of the Kordan Basin, secondly, the reasons for the fall and reduction were studied and clarified. Based on the present situation of the Plain it is necessary for the relevant organizations, especially the Ministry of Power and Agriculture, to have a joint project with joint planning. There should be some short, mid and long-term projects and in the mid and short term there must be strategic management to keep the water level stable. For the long-term projects, the objective should be focused on both water and agricultural.

Keywords: water balance, budget elements, water year, budget area, Kordan Basin, Hashtgerd Plain.
\end{abstract}

\section{Introduction}

As Iran has an arid and semi-arid climate, water is an invaluable asset and its use needs proper programming and sometimes critical management. In order to 
accomplish any type of water plans, the first step of programming will be gathering data. Afterwards, having applied different approaches, the plan can be put into effect. In hydrological plans, the water balance is considered as one of the main elements as it is essential for optimized utilization and water resource management. Thus, the water budget of the Kordan Basin (Hashtgerd Plain) is prepared due to its critical situation and status. During the past forty years, the water consumption of the Kordan Basin has dramatically increased because of the increasing population, which has been due to migration, expansion of farms, the establishment of numerous factories etc. Consequently, excessive water consumption has caused not only water pollution in this area, but also a fall in the level of ground water, which is more significant. The sharp fall in the level of ground water in Hashtgerd Plain has been studied by different researchers, private companies and state organizations and in these papers the fall in ground water level and the decrease in aquifer volume and pollution is examined. In the present study, the water balance of water year 1996-97 has been prepared based on the previous information and measurements $[12,14]$.

\section{The study approach to water balance preparation}

In order to examine the ground water balance of the area of the study, there should be precise information about recharge, input flow, discharge and utilization of water resources, draining, evaporation and finally changes in the ground water level and volume of the reservoir in a certain period and area. In the present study, the following eqn. (1) has been applied [1, 2, 10, 15-17]:

$$
\mathbf{Q}_{\text {in }}+\mathbf{R}_{\mathrm{p}}+\mathbf{R}_{\mathbf{r}}+\mathbf{R}_{\mathrm{w}}-\left(\mathbf{Q}_{\text {out }}+\mathbf{D}+\mathbf{E}+\mathbf{W}\right)= \pm \Delta \mathbf{V}
$$

In eqn. (1), the budget parameters are defined as follows:

$\mathbf{Q}_{\text {in }}$ : the amount of ground water input to the budget area, $\mathbf{Q}_{\text {out }}$ : the amount of ground water output from the budget area, $\mathbf{R}_{\mathbf{p}}$ : rate of direct rainfall water infiltration, $\mathbf{R}_{\mathbf{r}}$ : rate of recharge from the floods, $\mathbf{R}_{\mathbf{w}}$ : rate of infiltration of agricultural water return, D: draining from the aquifer by any draining systems or rivers, $\mathbf{E}$ : rate of evaporation from the shallow water aquifer surface in the budget area, $\mathbf{W}$ : ground water discharge, $\pm \Delta \mathbf{V}$ : the changes in the reservoir volume of the aquifer in a certain time and place .

\subsection{The geographical, geological and climatic situation of the budget area}

The budget area is situated at $36^{\circ}-05^{\prime}$ and $36^{\circ}-45^{\prime}$ latitudes and $50^{\circ}-55^{\prime}$ to $50^{\circ}$ 30 ' longitudes, see fig. 1 .

The budget area is $468.45 \mathrm{~km}^{2}$ wide and in the north west of Tehran between Kordan and Abyek, see fig 2. The area is formed by plio-quaternary alluvia and is of great significance from the hydro-geological point of view, which is chronologically as shown in table $1[4,6,9]$. In order to examine the climatic condition and by using the meteorology stations in the study area and its surroundings, the average annual temperature of Hashtgerd Plain is $13.2^{\circ} \mathrm{C}$. The 


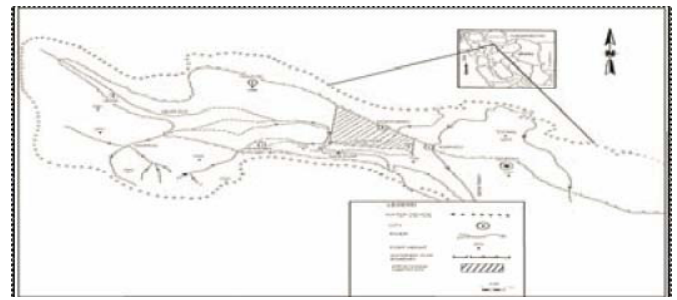

Figure 1: The geographical situation of the study area in Hashtgerd Plain.

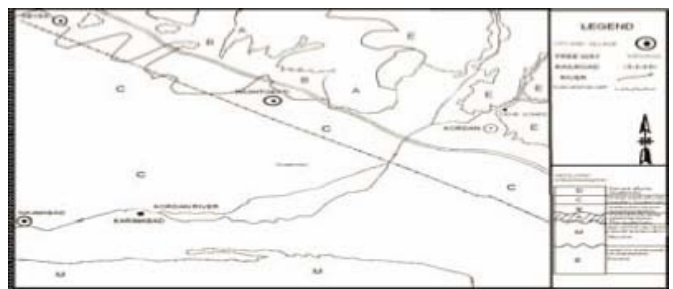

Figure 2: $\quad$ The geological map of Hashtgerd Plain and budget area.

Table 1: Geological specification of the Kordan Basin and the budget area.

\begin{tabular}{|c|l|l|}
\hline Series & Geological and Hydro geological Specifications & Age \\
\hline D & Cobble and gravel, sand & Recent Era \\
\hline C & $\begin{array}{l}\text { Gravel, sand, silt and clay; forms the main aquifer; significant } \\
\text { thickness, high permeability; more tiny-grain materials as you go } \\
\text { towards the south }\end{array}$ & Quaternary \\
\hline B & $\begin{array}{l}\text { Weak cement, gravel and sand, and silt; darker and more } \\
\text { heterogenic than A, unconformity with A series }\end{array}$ & $\begin{array}{l}\text { Plio- } \\
\text { Pleistocene }\end{array}$ \\
\hline A & $\begin{array}{l}\text { Conglomerate, sand, and gravel and lime, semi-hard cement; Dip } \\
5^{\circ} \text { to 20 } 0^{\circ} \text { toward the south, unconformity with Upper Red Form. } \\
\text { \& Eocene Form. }\end{array}$ & Pliocene \\
\hline M & $\begin{array}{l}\text { Upper Red formation; evaporative sediment (gypsum, anhydrate) } \\
\text { Clay \& Silt stone, unconformity E Form. \& A series }\end{array}$ & $\begin{array}{l}\text { Upper } \\
\text { Miocene }\end{array}$ \\
\hline E & $\begin{array}{l}\text { Volcanic Material (Andesine, Tuff, Basalt, Shale), limestone and } \\
\text { agglomerate }\end{array}$ & Eocene \\
\hline
\end{tabular}

annual evaporation rate based on the present statistical information is 2000 to $2300 \mathrm{~mm}$ and is at it's uppermost in June-July and the lowest amount in January and February $[1,9,11,13]$.

The 25 year statistical information (1971-1996) shows that the average gradient of annual precipitation of Hashtgerd Plain has been obtained by using eqn. (2);

$$
\mathrm{P}=0.3006 \mathrm{H}-132.12
$$

Based on eqn. (2), the average precipitation of Hashtgerd Plain is $240 \mathrm{~mm}$ and in the water year 1996-97 this rate is $130.5 \mathrm{~mm}$. To determine the climatic situation of Kordan Basin, the De Martonne and Emberger approaches have been used. 
The Plain is semi-arid according to De Martonne, dry, and cold according to Emberger [1, 9, 12, 14].

\subsection{The budget elements calculation}

The budget elements have been examined one by one in this section $[2,12,15]$ :

\subsubsection{The input ground water flow into the budget area (Qin)}

The input sections of the ground water were studied and examined with respect to the budget area map (fig. 3) and based on the Darcy equation. The Darcy equation, which can be used in table 2, is $\mathrm{Q}=\mathrm{T}$.L.I. According to table 2 , the rate of input water into the aquifer reservoir in water year 1996-97 is 37.118 MCM.

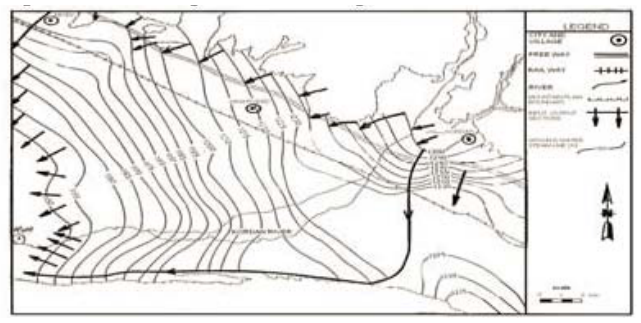

Figure 3: The ground water input-output direction of budget the area in Hashtgerd Plain (Kordan Basin).

Table 2: $\quad$ The input ground water flows in different sections into the budget area in water year 1996-97(* million cubic meter) $[12,14]$.

\begin{tabular}{|c|c|c|l|l|l|}
\hline $\begin{array}{l}\text { Section } \\
\text { no. }\end{array}$ & $\begin{array}{l}(\mathrm{L}) \\
(\mathrm{Km})\end{array}$ & $\begin{array}{l}(\mathrm{I}) \\
1.1000\end{array}$ & $\begin{array}{l}(\mathrm{T}) \\
\mathrm{m}^{2} / \text { day }\end{array}$ & $\begin{array}{l}\text { Budget } \\
\text { Period } \\
(\text { day })\end{array}$ & $\begin{array}{l}(\mathrm{Q}) \\
\text { MCM }^{*}\end{array}$ \\
\hline 1 & 0.77 & 12.94 & 810 & 365 & 2.946 \\
\hline 2 & 1.65 & 8.8 & 624 & 365 & 3.307 \\
\hline 3 & 1.7 & 7.85 & 360 & 365 & 1.753 \\
\hline 4 & 0.88 & 13.75 & 360 & 365 & 1.590 \\
\hline 5 & 1.02 & 10.47 & 250 & 365 & 0.955 \\
\hline 6 & 2.2 & 12.94 & 270 & 365 & 2.805 \\
\hline 7 & 2.97 & 13.75 & 280 & 365 & 4.174 \\
\hline 8 & 3.63 & 4.4 & 960 & 365 & 5.596 \\
\hline 9 & 1.92 & 5.79 & 1350 & 365 & 5.478 \\
\hline 10 & 1.18 & 6.28 & 1100 & 365 & 2.975 \\
\hline 11 & 1.15 & 6.47 & 840 & 365 & 2.281 \\
\hline 12 & 1.37 & 3.66 & 500 & 365 & 0.915 \\
\hline 13 & 2.31 & 2.75 & 480 & 365 & 1.113 \\
\hline 14 & 1.65 & 3.55 & 480 & 365 & 0.737 \\
\hline 15 & 1.54 & 2.44 & 360 & 365 & 0.493 \\
\hline Total & 25.94 & & & 365 & 37.118 \\
\hline
\end{tabular}




\subsubsection{Surface recharge of the budget area}

In the budget area, the surface recharge is done by precipitation, floods, agricultural water return, sewage and the base flow of the river, which depends on the climatic situation, weak plant coverage and geological structures for the surface recharge. In order to calculate the budget area recharge by precipitation or the rate of infiltration (Rp), two methods, Thronthwhite and the method referring to F.A.O [5] periodicals are used. In these two methods, parameters such as precipitation, temperature and potential evaporation are considered.

A. Calculating the recharge by referring to F.A.O periodicals and using eqn. (3) $[5,14]$ :

$$
\mathrm{F}=0.8(\mathrm{R}-\mathrm{C} \log \mathrm{Ep})^{1.5}
$$

In eqn. (3), the parameters are defined as follows:

$\mathbf{F}$ : the rate of infiltration in a month $(\mathrm{mm}), \mathbf{R}$ : monthly precipitation $(\mathrm{mm})$,

C: temperature coefficient of infiltration, Ep: Monthly potential evaporation $(\mathrm{mm})$. The summary of the calculation can be seen in table 3. In water year 1996-97, the total infiltration was 8.31MCM that has been added to the aquifer reservoir (table 3 ).

B. Recharge calculation applying the Thronthwhite approach, the summary of which can be seen in table 4. In this table Ep is potential evaporation and Etr is real evaporation [12]. Having compared the above approaches, we come to a result that the rates of infiltration are approximately equal; the differences, however, are due to first the faults in measurement and, secondly the shortcomings in the measurement spots. Considering the $468.45 \mathrm{Km}^{2}$ budget area, the height of precipitation in the water in year 1996-97 was $130.5 \mathrm{~mm}$. The amount of water infiltration into the aquifer in the F.A.O. method is $8.31 \mathrm{MCM}$ and for the Thronthwhite method is 8.75 MCM. Considering both methods, the average rate of infiltration in Hashtgerd Plain has been $8.53 \mathrm{MCM}$ annually.

\subsubsection{Budget area recharge by surface flows and floods $\left(R_{r}\right)$}

Concerning the climate and the very weak plant coverage situation of the area, one of the most important ways of recharging the aquifer of the budget area is by the surface flows and floods. By taking the 44-year statistical information of the

Table 3: Calculation of infiltration rate from precipitation of the budget area applying F.A.O for 1996-97 [5,14].

\begin{tabular}{|l|l|l|l|l|l|l|l|l|l|l|l|l|l|}
\hline M P & O & N & D & J & F & M & A & M & J & J & A & S & T \\
\hline${ }^{\circ} \mathrm{C}$ & 16.1 & 9.3 & 5,5 & 5.4 & -0.8 & 4.7 & 9.6 & 17.1 & 23.1 & 26.9 & 27.8 & 21.2 & \\
\hline C & 2.08 & 1.68 & 1.34 & 1.32 & 0 & 1.26 & 1.7 & 2.12 & 2.34 & 2.38 & 2.39 & 2.28 & \\
\hline R & 11.5 & 2 & 0 & 20 & 5 & 33 & 46.5 & 5.5 & 2.5 & 4.5 & 0 & 0 & 130.5 \\
\hline Ep & 110 & 91.9 & 48.7 & 48.3 & 29.4 & 45.7 & 100.3 & 166.5 & 214.1 & 249.1 & 421.6 & 200.6 & 1726.2 \\
\hline F & 2.15 & 0 & 0 & 3.37 & 1.78 & 4.44 & 5.25 & 0.71 & 0 & 0 & 0 & 0 & 17.70 \\
\hline F1 & 1.0 & 0 & 0 & 1.6 & 0.83 & 2.08 & 2.46 & 0.91 & 0.33 & 0 & 0 & 0 & 8.31 \\
\hline
\end{tabular}


Table 4: Calculation of infiltration rate from precipitation of the budget area applying Thronthwhite approach for 1996-97.

\begin{tabular}{|l|l|l|l|l|l|l|l|l|l|l|l|l|l|}
\hline $\mathrm{M} \mathrm{P}$ & $\mathrm{O}$ & $\mathrm{N}$ & $\mathrm{D}$ & $\mathrm{J}$ & $\mathrm{F}$ & $\mathrm{M}$ & $\mathrm{A}$ & $\mathrm{M}$ & $\mathrm{J}$ & $\mathrm{J}$ & $\mathrm{A}$ & $\mathrm{S}$ & $\mathrm{T}$ \\
\hline${ }^{\circ} \mathrm{C}$ & 16.1 & 9.3 & 5.5 & 5.4 & -0.8 & 4.7 & 9.6 & 17.1 & 23.1 & 26.9 & 27.8 & 21.2 & \\
\hline $\mathrm{Ep}$ & 60.7 & 23 & 10.2 & 0 & 0 & 11.7 & 25.2 & 82.8 & 131.6 & 168.4 & 167.1 & 98 & 789 \\
\hline $\mathrm{R}$ & 11.5 & 2 & 0 & 20 & 5 & 33 & 46.5 & 5.5 & 2.5 & 4.5 & 0 & 0 & 130.5 \\
\hline Etr & 11.5 & 2 & 0 & 10 & 0 & 11.7 & 25.2 & 15.5 & 2.5 & 4.5 & 0 & 0 & 82.9 \\
\hline $\mathrm{F}$ & 0 & 0 & 0 & 5 & 2.5 & 5.6 & 5.6 & 0 & 0 & 0 & 0 & 0 & 18.7 \\
\hline $\mathrm{F} 1$ & 0 & 0 & 0 & 2.34 & 1.17 & 2.62 & 2.62 & 0 & 0 & 0 & 0 & 0 & 8.75 \\
\hline
\end{tabular}

$\mathrm{T}$ : Total, ${ }^{\circ} \mathrm{C}$ : Temperature, F1: Infiltration (MCM or million cubic meter), M: month, P: parameter.

Kordan River into account, the average discharge is $3.52 \mathrm{~m}^{3} / \mathrm{s}$. Considering the amount of river discharge, physiographic, morphologic situations and the configuration of riverbed soil, the rate of recharge for the Hashtgerd Plain's aquifer in the water year 1996-97 in total is $39.76 \operatorname{MCM}[9,11,12,14]$.

\subsubsection{The returned water of agriculture and city sewage $\left(R_{w}\right)$}

There are 2099 active wells for agricultural and drinking consumption in the Hashtgerd Plain area. Out of this number of wells in the water year of 1996-97, about 200.59 MCM of water has been discharged. The total amount of water used for agriculture is $166.78 \mathrm{MCM}$ and by considering the type and the texture of soil and the watering system in Hashtgerd Plain and if we consider the agriculture water return as $40 \%$, then there would be $66.7 \mathrm{MCM}$ water return into the aquifer. Considering the information about the studied water year, about 33.81 MCM of water has been used for drinking and industrial applications. This is, however, in such a way that the city and village sewage and also the factory wastes are discharged through the absorbing wells and consequently, the returned water into the aquifer i.e. its recharge can be estimated as $21.97 \mathrm{MCM}$ with regards to the soil configuration condition which is about $60 \%[9,13,14]$.

\subsubsection{The ground water output flow from the budget area ( $Q$ out)}

Once the budget area is cleared, as was explained in the input sections, by using the budget area map (fig.3) and the Darcy equation, the output section was determined and the volume of output water was calculated. For the 1996-97water year, a total of $8.16 \mathrm{MCM}$ water has exited as output flow from the aquifer of the budget area $[8,12,14]$.

\subsubsection{Evaporation from the ground water in the budget area (E)}

In order to measure the amount of evaporation in the ground water, it is necessary to draw the iso depth map of the ground water level to determine the depth of under 5-meter deep spots. As the map shows, those spots are mostly seen in the west and south west of the budget area, i.e. in the outer part of the area. The volume of the evaporated water in those spots in the water year 199697 is $1.87 \mathrm{MCM}[2,12,14]$. 
Table 5: The output flows of ground water in different sections of budget area in water year 1996-97 (*million cubic meter).

\begin{tabular}{|l|l|l|l|l|l|}
\hline $\begin{array}{l}\text { Section } \\
\text { No. }\end{array}$ & $\begin{array}{l}(\mathrm{L}) \\
(\mathrm{Km})\end{array}$ & $(\mathrm{I})(\%)$ & $\begin{array}{l}(\mathrm{T}) \\
\mathrm{m}^{2} / \text { day }\end{array}$ & $\begin{array}{l}\text { Budget Period } \\
(\text { day })\end{array}$ & $(\mathrm{Q}) \mathrm{MCM}^{*}$ \\
\hline 1 & 1.77 & 5.55 & 250 & 365 & 0.896 \\
\hline 2 & 1.25 & 4 & 240 & 365 & 0.438 \\
\hline 3 & 1.17 & 2.66 & 350 & 365 & 0.397 \\
\hline 4 & 2.2 & 3.22 & 350 & 365 & 0.931 \\
\hline 5 & 1.8 & 3.07 & 360 & 365 & 0.686 \\
\hline 6 & 2.65 & 2.83 & 340 & 365 & 0.876 \\
\hline 7 & 1.81 & 2.85 & 320 & 365 & 0.606 \\
\hline 8 & 1.15 & 2.77 & 330 & 365 & 0.384 \\
\hline 9 & 1.56 & 3.27 & 320 & 365 & 0.596 \\
\hline 10 & 1.4 & 3.48 & 300 & 365 & 0.533 \\
\hline 11 & 1.26 & 3.84 & 320 & 365 & 0.565 \\
\hline 12 & 0.9 & 4.08 & 320 & 365 & 0.429 \\
\hline 13 & 0.85 & 4.6 & 300 & 365 & 0.428 \\
\hline 14 & 1.2 & 4.54 & 200 & 365 & 0.398 \\
\hline Total & 20.98 & & & 365 & 8.160 \\
\hline
\end{tabular}

\subsubsection{Discharge from the ground water of the budget area $\left(Q_{w}\right)$}

According to statistical information from the Local Water Organization of Karaj, there are 2099 active wells in the budget area. The working hours, consumption rate and the annual discharge rate of each well have been measured. Based on above inspection, about 200.59 MCM water has been discharged annually [9, 11, $12,14]$.

\subsubsection{Calculating changes in aquifer reservoir volume in the budget time and area $( \pm \Delta \mathbf{V})$}

To measure the changes in the reservoir volume eqn. (4) has been used $[7,12]$ :

$$
\pm \Delta \mathrm{V}=( \pm \Delta \mathrm{h}) . \mathrm{A} . \mathrm{S}
$$

In the above equation:

$\pm \Delta \mathbf{V}$ : changes in the reservoir volume (MCM), $\pm \Delta \mathbf{h}$ : water level fluctuation $(\mathrm{m})$, A: the area of the budget $\left(\mathrm{Km}^{2}\right), \mathbf{S}$ : the storage coefficient $(\%)$.

The water level fluctuation in the budget area has been constantly measured during the study time and also, besides drawing the water level (fig.3) and water level exchange map, the local unit hydrograph for the year 1996-97 is drawn by applying the graph of water level fluctuations (fig. 4). Based on the above, as can be seen in the unit hydrograph, the water level has risen $1.24 \mathrm{~m}$ in the wet period and declined $2.94 \mathrm{~m}$ in the dry period. Generally, the water level in the study year has declined $1.7 \mathrm{~m}$ compared with the previous year.

According to eqn. (4), one of the most important parameters is determining the aquifer storage coefficient. Due to the major economical problems, working out on this coefficient depends only on a few pumping tests and slug tests, which do not include all of the budget area. By a trial and error approach there has been an attempt to calculate the coefficient. As a result, concerning the approaches applied, the average storage coefficient for the studying area has been estimated as about $4.5 \%$. Knowing the size of the budget area and changes in the aquifer 


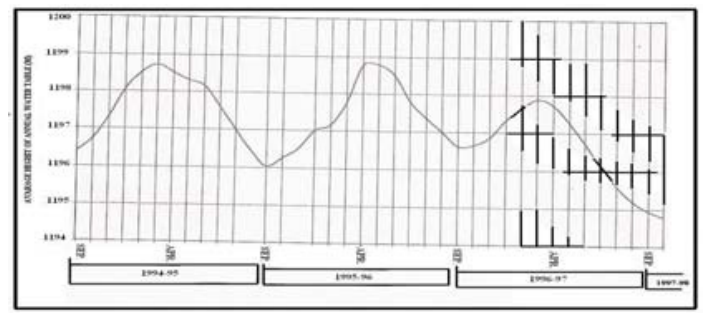

Figure 4: The unit hydrograph of the ground water level of budget area.

volume in the water year 1996-97, in the wet period the $\Delta \mathrm{h}=1.24 \mathrm{~m}$, which equals 26.13 MCM and in dry period $\Delta \mathrm{h}=-2.94 \mathrm{~m}$, which is $-61.97 \mathrm{MCM}$ [12, 14]. Generally, with regard to the above calculations in the year when the rate of ground water fall was $1.7 \mathrm{~m}$, the changes in the aquifer reservoir volume of Hashtgerd Plain are -35.83 MCM, which indicates that in water year 1996-97 there has been excessive consumption from the reservoir volume. The summary of calculations of water year 1996-97 budget parameters is presented in table 6 . Accordingly, most characteristics have been estimated based on the present information, which has also caused some errors.

\section{Conclusion}

Iran has an arid to semi-arid climate and the percentage of its rainfall is normally low in some areas and very low in other areas. For several reasons, such as being

Table 6: Summary of the calculations of budget parameters of water year 1996-97 in Hashtgerd Plain. R: recharge, D: discharge, figures are MCM.

\begin{tabular}{|c|c|c|c|c|c|c|c|}
\hline \multirow{2}{*}{\multicolumn{2}{|c|}{$\begin{array}{l}\text { Description } \\
\text { Parameters }\end{array}$}} & \multicolumn{2}{|c|}{ Wet Period } & \multicolumn{2}{|c|}{ Dry Period } & \multicolumn{2}{|c|}{ Budget Period } \\
\hline & & $\mathrm{R}$ & D & $\mathrm{R}$ & D & $\mathrm{R}$ & D \\
\hline \multicolumn{2}{|l|}{ Qin } & 16.22 & & 21.65 & & 37.11 & \\
\hline \multirow{5}{*}{$\begin{array}{l}\text { Recharge } \\
\text { from } \\
\text { Plain }\end{array}$} & $\mathrm{Rp}$ & 4 & & 4.53 & & 8.53 & \\
\hline & $\mathrm{Rr}$ & 35.25 & & 4.51 & & 39.76 & \\
\hline & Rw & 10.64 & & 56.06 & & 66.7 & \\
\hline & Rw & 8.18 & & 13.78 & & 21.97 & \\
\hline & $\mathrm{Rr}$ & 1.27 & & 4.50 & & 5.78 & \\
\hline \multicolumn{2}{|l|}{ Qout } & & 3.4 & & 4.76 & & 8.16 \\
\hline \multicolumn{2}{|l|}{ Qw } & & 26.6 & & 140.18 & & 166.78 \\
\hline \multicolumn{2}{|l|}{ Qw } & & 12.59 & & 21.21 & & 33.81 \\
\hline \multicolumn{2}{|l|}{$\bar{E}$} & & 0.29 & & 1.58 & & 1.87 \\
\hline \multicolumn{2}{|l|}{$\pm \Delta \mathrm{V}$} & 26.13 & & 61.97 & & 35.83 & \\
\hline \multicolumn{2}{|l|}{ Total } & 101.69 & 42.88 & 167 & 167.73 & 215.68 & 210.62 \\
\hline
\end{tabular}


near to Tehran, which has made it a summer residence, the fertility of the soil for agriculture and the rapid industrial development have caused a lot of people to migrate to this area and choose it as their residence, thus, this causes the growth of population. However, with this limited rainfall, firstly because of the absence of infrastructures and then because of the economical problems and also not implementing the related water projects, control and prevention of this source from wasting would be impossible and as a result it would npt be possible to make good use of the present potentials of the area. In a way, consuming the water of the Kordan River and other seasonal rivers during the cold months of the year would be impossible and these rivers would finally join the Salt Rivers and will be destroyed.

According to long term statistics and different budgets prepared in recent years, for instance in the water years 1993-94 and 1996-97 it can be found out that from the year 1994 to 1995 the consumption of water has increased by an average of 30-40 MCM. This fact has been proved by the decline of the ground water level, because during the past 30 years in different areas of the balance sheet the level of the ground water has declined about 2-4 meters. On the other hand, the everyday increase of the population, increase in the lands under agriculture and also the increasing number of the factories have caused polluted civil and rural sewage, and factory and agriculture wastes enter the aquifer and pollute them. The budget prepared in the water year 1996-97 shows that in the same year the amount of $35.83 \mathrm{MCM}$ extra water has been used in the aquifer reservoir. The capacity of the aquifer reservoir has decreased and this matter has been proved in the Plain hydrograph unit with a decline of a $1.7 \mathrm{~m}$. As explained above, beside the recharge of Hashtgerd Plain aquifer from returned water of industrial, agricultural and drinking applications, it will be done through the infiltration of the surface water especially in the wet months of the year from the bed of the Kordan River and other seasonal rivers from the alluvial fan on the southern side of the Alborz mountain range. In addition, recharge will be done through the direct infiltration of rainfalls in the rainy months. On the other hand, the aquifer will be recharged through side-recharge of the Plain and from the north highlands. In return, there is no side-recharge in the southern heights of the Plain due to clay, marl and gypsum sediments in this area, which are considered as impermissible in texture. In contrast, because of the decline in the ground water level in this section, salt water has intruded into the aquifer, which has dramatically increased the amount of salt of the aquifer in the south and south west of the Plain. As was mentioned in the previous sections, because of such a fast growth of the population, which has been scarce in the past 30 years, cities and villages have been under-equipped with facilities such as sewage canalization systems. This, together with the dumping system for agricultural and industrial wastes, has caused the wastes to be discharged through the absorbing wells. The farmlands will become bigger as the population grows and on the other hand, in order to produce many more products, more chemical fertilizers will be used whose wastes could be become another source of contamination for the aquifer. One can conclude from the above discussions that some precise and certain short, mid and long-term projects and plans need to be 
put in place by organizations such as the Ministry of Power and Agriculture. Applying some strategic management in the first phases could also prevent the increase in losses and damages made so far and would keep the reservoir volume stable. Beside all these long-term issues, informing people via media could help change and improve their viewpoints. Eventually, the above plans can be accomplished by turning such issues into national wills.

\section{Suggestions}

The explanations given about the Hashtgerd Plain budget showed that in order to make the best use of the aquifer, it is necessary to make suggestions as follows to save this aquifer from its critical situation. In this case, before taking the suggestions into consideration, it is necessary to mention that one of the major and the most important problems is lack of adequate expert human resources and if this fact is considered as one of the problems, errors such as measurement faults will be minimized.

- Installation of complete weather forecast and hydrometric stations.

- By using G.P.S we can find the exact place of the present wells.

- In order to prepare a precise budget, it would be better to dig more wells for every $25 \mathrm{~km}^{2}$ of every individual observation well to get accurate information about water level and specification of the aquifer. It is suggested that for every 5 to $10 \mathrm{~km}^{2}$, an exploring well will be dug and pump testing will be performed in order to have more information for a more accurate budget.

- It is suggested that in order to modify the exact hydrodynamic specifications of the aquifer and the flow of the ground water the relevant authorities mainly the Ministry of Power and Agriculture carry out more experiments and testing in the area under study to obtain more precise information. In addition, to modify the soil humidity and in order to calculate the rate of the soil infiltration, it is necessary to make a number of lysimeters to cover the whole area cause having this information for the non-saturation zone of the soil would be obligatory.

- In the first stage one of the major tasks which should be carried out by the relevant authorities (Ministries of Power and Agriculture) is:

1. Identifying illegally dug wells and blocking them in the budget area.

2. It would be better if legally dug wells could be equipped with gauge instruments to let the well owners utilize with an issued license.

- To prepare a budget, having information and statistics from surface water resources would be obligatory thus it is suggested that by considering the critical conditions of the budget area, sampling and collecting statistical figures of the present water resource of the area should be done at least twice a month and in normal conditions once a month.

- On the east coast of the Kordan River, a soil canal to give water to the farmers has been built, where, being exposed and due to its soil-like surface, a great amount of this water will be evaporated, especially in hot seasons, 
and the remainder will penetrate and as a result this way of watering would be less efficient. It is suggested that this canal could help the farmers through closed pipes.

\section{References}

[1] Alizadeh, A., the Principles of Applied Hydrology, Astan Ghods Razavi, Mashhad, Iran, 2004.

[2] Castany, G., Traite Pratique des eaux souterraines, Dunod, FRANCE, 1963

[3] C.G.G. Co, Geophysics Study report of Hashtgerd Plain, Tehran, Iran, 1967

[4] Darvishzadeh, A., the Geology of Iran, Danesh-e-Emrooz, Tehran, Iran, 1991.

[5] F.A.O. Publication No. 38, Geneva, Switzerland, 1980.

[6] Geology Organization of Iran, geological map of Tehran, Ghazvin and Saveh with scale 1/250000, 1991

[7] Honarmand, E.I., Calculating Transmissibility Coefficient of the Aquifer of ground water by using Piezometric, Bulletin No. 4, 1981.

[8] Honarmand E.I., Calculating transmissibility coefficient of the aquifer of ground water by using Piezometric, geophysics studies, Bulletin No. 4, 1981

[9] Kavab Engineering Consultancy, Hydrology Report of Hashtgerd Plain, Tehran, Iran, 1984.

[10] Ministry of Power, the Office of Water Resource, Observation ways to prepare budget, bulletin No.85, Tehran, Iran, 1994

[11] Ministry of Water and Electricity, Head Quarter of ground water, semi descriptive report of Hashtgerd Plain, Tehran, Iran, 1972.

[12] Moghimi, H., Tahran batisi Karaj Ovasinin Hydrojeoloji Incelemesi, Doktora tezi, Ankara universitesi, Ankara, Turkiye, 1996

[13] Pazhouhab Engineering Co., Report of water resource development of Kordan River Basin, Tehran, Iran, 1992.

[14] Sadjadian, M. R., Hydrogeology Studies, Artificial recharge and Mathematical Model of Hashtgerd Plain ground water resources, A Thesis, The Science of Earth Faculty, Shahid Beheshti University, Tehran, Iran, 1998

[15] Schwartz, F.W., Zhang, H., Fundamentals of Ground water, John Wiley \& Sons, New York, U.S.A., 2002

[16] Todd, D.K., Groundwater hydrology, John Wiley \& Sons, New York, U.S.A., 1980

[17] Torabi T., P., Ground water Geo-hydrology, Boo Ali Sina University Publication No. 131, 2000 